Original research article

\title{
Investigating the attitude of ambulance workers towards death
}

\author{
Vladimír Moskola ${ }^{1 *}$, Csaba Eke ${ }^{2}$, Johanna Takács ${ }^{5}$, Éva. Susánszky ${ }^{3}$, Andrea Székely ${ }^{1}$, \\ István Hornyák ${ }^{1}$, Barbara Ozsvárt ${ }^{1}$, Tibor Néninger ${ }^{1}$, Zoltán Balogh ${ }^{4}$ \\ ${ }^{1}$ Semmelweis University, Faculty of Health Sciences, Department of Oxyology and Emergency Care, Budapest, Hungary \\ 2 Semmelweis University, Doctoral School of Basic and Translational Medicine, Budapest, Hungary \\ ${ }^{3}$ Semmelweis University, Faculty of Medicine, Institute of Behavioral Science, Budapest, Hungary \\ ${ }^{4}$ Semmelweis University, Faculty of Health Sciences, Department of Nursing, Budapest, Hungary \\ ${ }^{5}$ Semmelweis University, Faculty of Health Sciences, Department of Social Sciences, Budapest, Hungary
}

\section{Abstract}

Introduction: Attitudes towards death are influencing factors for burnout, and there are various manifestations and subscales of this attitude (fear of death, death avoidance, neutral acceptance, approach acceptance, escape acceptance).

Methods: The study was conducted between March 1, 2018, and February 28, 2019, among staff members of the "National Ambulance Service" and participants in the "National Ambulance Professionals of the Hungarian Chamber of Health Workers". For the study, we used the revised version of the Death-Attitude Profile questionnaire (DAP-R), developed by Wong/Reker/Gesser. Previously there was no Hungarian version, so we completed the translation process. The incoming answers were analyzed using the SPSS 25.0 statistical program.

Results: The translation process was successful. A total of 669 ambulance workers (emergency doctors, paramedics, ambulance technicians, ambulance nurses, ambulance drivers) participated in the study (male $-n=584,87.3 \%$, female $-n=83,12.4 \%$; mean age: 42.40 $(S D=10.41$, range $=20-64)$. Analyzing our database, the fear of death attitude subscale showed the smallest value $(M=2.77, S D=1.30)$, and the neutral acceptance subscale $(\mathrm{M}=5.86, \mathrm{SD}=1.22)$ showed the largest value.

Conclusions: The translation of the DAP-R questionnaire conducted in the first part of our study can be used as a referential basis for further studies in Hungary. Comparing our results to other studies in the international literature, fear of death is also present, to a greater extent than expected, but the characteristic attitude is neutral acceptance.
\end{abstract}

Keywords: Attitude to death; Hungary; Paramedics

\section{Introduction}

During rescue work, paramedics often encounter an unexpected death. Usually, these events occur unexpectedly and there is no opportunity to prepare for them (Edlich and Kübler-Ross, 1992; Olsen et al., 1998; Parrish et al., 1987; Schmidt et al., 1992). Sudden death or forthcoming death is a true crisis for the patient, family, and specialists (Hegedüs et al., 2001; Ordog, 1986). During a reanimation or working with a critically ill patient, specialists fight against death - but they know this job is just a fight against time. During this struggle they sometimes can't reach their goal, and the patients spend their last minutes and expel their final breaths in the arms of these workers. The pre-hospital environment is very special, and the types of sudden death are very diverse. The death of children is the biggest pressure for the ambulance workers, and it is described as a critical stressor in the literature (Donnelly and Siebert, 2009). In addition to this, the specialists have to pay attention to the psychological needs of the families of the patients. The ideal handling of sudden death requires good communication and empathy - skills which are taught poorly at schools and not very common in the scientific literature (Ordog, 1986). There have been no studies in Hungary that have examined this aspect of the work of ambulance specialists. In the past decades, there have been many theories of death and dying and the relationship between the patients and medical professionals (Copp, 1998). As Kastelbaum and Thuell (1995) recognized, these theories are not adequate for the scientific expectations and the present challenges.

They do, however, help us to understand the process of death and determine what needs to be done. Some theories are more popular in certain disciplines, while some contemporary studies offer critiques, alternatives, and modified ver-

\footnotetext{
* Corresponding author: Vladimír Moskola, Semmelweis University, Faculty of Health Sciences, Department of Oxyology and Emergency Care, Üllői út 26, H-1085 Budapest, Hungary; e-mail: moskolav@gmail.com http://doi.org/10.32725/kont.2021.007 
sions. The most current theory is the "five-step grievance procedure". The basis of this theory is a groundbreaking study by Dr. Elizabeth Kübler-Ross, a Swiss-American psychiatrist, who examined more than 200 dying patients and created the theory based on that experience (Kübler-Ross and Byock, 1969). The study focused on the psychosocial reactions of dying adult patients and led to the model of the five stages of grief, which since then has become the leading paradigm regarding the treatment of dying patients (Copp, 1998). According to the theory, when a patient or their adherents meet with death or are acquainted with the irrevocable fact of dying, they go through five stages: denial, anger, bargaining, depression, and acceptance. Although the theory is still very popular it has received harsh criticism (Corr et al., 2013). Many studies do not support this model, and medical workers who deal with death have found that this model is not appropriate, and is superficial and misleading (Corr, 2015). The main criticism of this theory is its mechanic approach, which suggests that the dying patient goes through the universal five stages (Copp, 1998), and the physical and spiritual dimensions are not included (Corr et al., 2013). The latest editions of popular emergency textbooks continue to refer to that model, even though it lacks unequivocal scientific trustworthiness (Corr et al., 2013).

To solve some of the problems with the Kübler-Ross theory, Buckman (1993) worked out a three-step model. According to this, a patient's coping mechanism (which was used in the past to solve difficult situations) corresponds to the mechanism of how a patient reacts in the face of death. This procession is influenced by individual characteristics (Copp, 1998). It is important to mention the phase-theory of consciousness, because it discusses the main aspects of communication and the behavior between medical workers and patients. In 1965, Glaser and Strauss analyzed the interactions between medical workers and critical patients based on their observations and interviews.Examining the behavior of patients and health care workers during the dying process, four correlations were found, namely: closed awareness, suspicion, mutual deception, and open awareness (Copp, 1998). During the phase of closed awareness, the medical workers are aware of the patient's bad forecast, but the patient is not yet informed. The phase of suspicion, as the name suggests, is an unstable situation in which a patient starts to presume the severity of the situation and the suspicion is tried to be verified. In that situation, there is a chance that the patient will die before the truth is acknowledged or the affirmation given. This leads to the phase of mutual deception - in which the patient and the medical workers mutually acknowledge that the patient is dying, but they pretend that there is a chance of survival. Open awareness comes when both the patient and medical workers acknowledge the fact that the patient is dying and decide to act accordingly (Copp, 1998). The theory about the procession of dying and the medical workers' appropriate acts comes from the work of Pattinson, who set up the following three stages: the stage of acute crisis, the stage of chronic death, and the final stage. The medical providers' role that they should react to the patient's various kinds of adaptions regarding the acute crisis, finally to allow that the patient could enter the final phase in an adequate way (Pattison, 1977). This clinical model comes from a combination of the psychodynamic and humanistic (Copp, 1998), and it considers the patient's feelings and reactions as well as the family's ways of dealing with death and the acceptance of loss. Lastly, the model of Corr (1992) should also be highlighted. He based his theory on the four dimensions of human life, namely the psychical, the psychological, the social and the spiritual needs. The support of the acceptance of death should be given in more dimensions according to him (Corr, 2015; Corr et al., 2013).

The purpose of this study was to discover the attitude of paramedics towards death, and to find a connection between the sample's demographical, socioecological parameters and between the factors of work, workplace, and health-attitude.

\section{Materials and methods}

\section{Participants in the study}

A total of 669 ambulance workers (emergency doctors, paramedics, ambulance technicians, ambulance nurses, ambulance drivers) participated in the study (male $-n=584,87.3 \%$, female $-n=83,12.4 \%$; mean age: 42.40 (SD = 10.41, range $=$ 20-64). They had been working at the National Ambulance Service for at least six months - and worked without supervision.

\section{Data collection}

The online data collection took place between March 1, 2018, and February 28, 2019. The questionnaire was sent to the e-mail address of the internal, closed staff of the National Ambulance Service (NAS). We also sent the questionnaire to the email addresses at the database of the National Ambulance Professional Member of the Hungarian Chamber of Health Workers (HChHW). According to NAS's November 2018 registration data, 6,412 people were in active employment at the time of the survey ( $88 \%$ men and $12 \%$ women).

\section{Measurements}

A revised version of the Death Attitude Profile questionnaire DAP-R (Kulcsár, 2002; Wong et al., 1994) was used to measure attitudes toward death. It contains 32 chapters, and it measures the attitude towards death on 5 scales: Avoidance, Fear of death, Acceptance of waiting, Acceptance as an escape, and Neutral Acceptance. The degree of agreement with the statements should be rated by the respondent on a scale of 1-7 ( 1 = "not at all" and 7 = "completely". Our workgroup translated the original questionnaire into Hungarian with the help of five professional translators, and with the help of another five translators we translated it back to English. We found no major difference between the two English texts, so we can conclude that the Hungarian translation can be used at a scientific level. We made a report of the translation process. The questionnaire included demographic variables such as, workplace, work, financial status, lifestyle, alcohol, coffee, energy drink consumption data, and religious issues (see Annex).

\section{Statistical analysis}

The incoming answers were analysed using the IBM SPSS Statistics for Windows, Version 25.0 (IBM Corp. Released 2017, Armonk, NY: IBM Corp.) We performed descriptive statistical analysis. To analyse our database we used two-sample t-tests, correlation calculations, and analysis of variance with post-hoc tests (Bonferroni).

\section{Results}

\section{Characteristics of the sample}

Sociodemographic parameters of the sample, work and workplace parameters, and characteristics related to health and risk behaviours are shown in Table 1. 
Table 1. Sociodemographic, work and workplace, health and risk behaviours in the sample

\begin{tabular}{|c|c|c|c|c|c|c|c|c|}
\hline \multicolumn{3}{|c|}{ Sociodemographic parameters } & \multicolumn{3}{|c|}{ Work parameters } & \multicolumn{3}{|c|}{ Health and risk behaviours } \\
\hline Marital status & $n$ & $\%$ & Title & $n$ & $\%$ & Sports & $n$ & $\%$ \\
\hline unmarried & 90 & 13.7 & medical doctor & 24 & 3.7 & none or rare & 276 & 42.4 \\
\hline with partner & 110 & 16.8 & paramedic & 181 & 28.1 & daily & 41 & 6.3 \\
\hline married & 390 & 59.5 & ambulance technician & 64 & 12.7 & a few times a week & 126 & 19.3 \\
\hline divorced & 65 & 9.9 & ambulance nurse & 299 & 46.4 & two times a week & 77 & 11.8 \\
\hline \multirow[t]{2}{*}{ widow/er } & 1 & 0.2 & ambulance driver & 58 & 9.0 & weekly & 90 & 13.8 \\
\hline & & & & & & monthly & 42 & 6.4 \\
\hline Education & $n$ & $\%$ & Number of jobs & $n$ & $\%$ & Alcohol & $n$ & $\%$ \\
\hline secondary school & 36 & 5.4 & one & 209 & 32.1 & none or rare & 332 & 50.7 \\
\hline technical college & 72 & 10.9 & two & 270 & 41.4 & daily & 9 & 1.4 \\
\hline high school & 45 & 6.8 & three & 126 & 19.3 & a few times a week & 72 & 11 \\
\hline technical (further) & 243 & 36.8 & four & 40 & 6.1 & two times a week & 62 & 9.5 \\
\hline college, BSc & 213 & 32.2 & five & 7 & 1.1 & weekly & 102 & 15.6 \\
\hline university, MSc & 50 & 7.6 & & & & monthly & 78 & 11.9 \\
\hline $\mathrm{PhD}$ & 2 & 0.3 & & & & & & \\
\hline \multirow{4}{*}{$\begin{array}{l}\text { Religious } \\
\text { yes } \\
\text { no }\end{array}$} & $n$ & $\%$ & Years spent at work & $M$ & SD & Cigarettes & $n$ & $\%$ \\
\hline & 302 & 45.8 & & 16.73 & 11.36 & none & 442 & 67.0 \\
\hline & 357 & 54.2 & & & & $<10$ cig/day & 61 & 9.2 \\
\hline & & & & & & $>10$ cig/day & 157 & 23.8 \\
\hline \multirow{8}{*}{$\begin{array}{l}\text { Children } \\
\text { none } \\
\text { one } \\
\text { two } \\
\text { three } \\
\text { four } \\
\text { five } \\
\text { six or more }\end{array}$} & $n$ & $\%$ & Work hours/month & $n$ & $\%$ & & & \\
\hline & 164 & 26.1 & $12-24 \mathrm{~h}$ & 13 & 2.0 & & & \\
\hline & 127 & 20.2 & $36 \mathrm{~h}$ & 4 & 0.6 & & & \\
\hline & 196 & 31.2 & $48 \mathrm{~h}$ & 12 & 1.8 & & & \\
\hline & 99 & 15.8 & $60 \mathrm{~h}$ & 17 & 2.6 & & & \\
\hline & 29 & 4.6 & $84 \mathrm{~h}$ & 34 & 5.2 & & & \\
\hline & 10 & 1.6 & $120 \mathrm{~h}$ & 10 & 1.5 & & & \\
\hline & 3 & 0.5 & $168 \mathrm{~h}$ & 564 & 86.2 & & & \\
\hline
\end{tabular}

\section{Internal consistency of DAP-R questionnaire}

In the sample of ambulance workers, the subscales had acceptable reliability (0.75-0.92). We worked with the following subscales: Avoidance (numer of items: 5, Cronbach alfa: 0.854), Acceptance of waiting (10, CA = 0.925), Acceptance as an escape $(5, C A=0.787)$, Fear of death $(7, C A=0.843)$ and Neutral acceptance $(5, C A=0.750)$.

In the sample of ambulance workers, the fear of death subscale showed the lowest points and neutral acceptance showed the highest. For descriptive statistics see Table 2.

\begin{tabular}{lcc}
$\begin{array}{l}\text { Table 2. DAP-R subscales in the sample of ambulance } \\
\text { workers }\end{array}$ & M & SD \\
\hline & 2.77 & 1.30 \\
\hline Fear of death & 3.43 & 1.75 \\
Avoidance & 5.86 & 1.22 \\
Neutral acceptance & 3.31 & 1.73 \\
Acceptance of waiting & 3.12 & 1.60 \\
\hline Acceptance as an escape & &
\end{tabular}

\section{Relationship between the attitude towards death and sociodemographic parameters in ambulance workers} There was a significant difference between males and females in two subscales: Avoidance $(t(640)=3.125, p<0.001)$ and Acceptance as an escape $(t(646)=2.595, p=0.011)$. Males showed a higher score on these subscales than females (Avoidance: male $-\mathrm{M}=3.51, \mathrm{SD}=1.74$, female $-\mathrm{M}=2.86, \mathrm{SD}=1.73$; Acceptance as an escape: male $-\mathrm{M}=3.18, \mathrm{SD}=1.62$, female $\mathrm{M}=2.74, \mathrm{SD}=1.39$ ).

Examining the level of education, two subscales showed a significant difference between the education groups: Avoid- ance $(F(5,630)=12.103, p<0.001)$ and Acceptance of waiting $(F(5,630)=4.468, p=0.001)$. Based on Games-Howell posthoc test, a higher level of education ( $\mathrm{BSc}, \mathrm{MSc} / \mathrm{PhD}$ ) related to a lower score in Avoidance, and a higher score in Acceptance of waiting (Table 3).

\begin{tabular}{|c|c|c|c|c|}
\hline & \multicolumn{2}{|c|}{ Avoidance } & \multicolumn{2}{|c|}{$\begin{array}{c}\text { Acceptance of } \\
\text { waiting }\end{array}$} \\
\hline & M & SD & M & SD \\
\hline Secondary school & 3.93 & 1.72 & 3.11 & 1.64 \\
\hline Technical college & 3.81 & 1.87 & 2.63 & 1.48 \\
\hline High school & 3.49 & 1.80 & 3.80 & 1.66 \\
\hline Technical (further) & 3.87 & 1.73 & 3.24 & 1.74 \\
\hline College, BSc & 2.92 & 1.55 & 3.52 & 1.79 \\
\hline University, MSc, $\mathrm{PhD}$ & 2.46 & 1.54 & 3.55 & 1.74 \\
\hline
\end{tabular}

Religious showed a significant relationship with two scales of death attitudes: Acceptance of waiting $(t(632)=16.047$, $p<0.001)$ and Acceptance as an escape $(t(638)=2.847, p=$ $0.005)$. Religious people had a higher score in these subscales than non-religious people (Acceptance of waiting: religious $\mathrm{M}=4.35, \mathrm{SD}=1.89$, non-religious $-\mathrm{M}=2.46, \mathrm{SD}=1.33$; $\mathrm{Ac}-$ ceptance as an escape: religious $-\mathrm{M}=3.32, \mathrm{SD}=1.68$, non-religious $-\mathrm{M}=2.96, \mathrm{SD}=1.50$ ).

The number of children has a significant relationship with two subscales: Avoidance $(F(3,602)=4.190, p=0.006)$ and Acceptance of waiting $(F(3,603)=4.134, p=0.007)$. Based on the Games-Howell post-hoc test, in case of Avoidance ambulance 
workers without children showed the lowest score and with one child had the highest score. On the Acceptance of waiting, workers with one child had the lowest score and those with three or more children had the highest score. The child is visible in the commitment category as an intermediate score on these subscales (Table 4).

Table 4. Avoidance and acceptance of waiting subscales by the number of children in ambulance workers

\begin{tabular}{lcccc}
\hline & \multicolumn{2}{c}{ Avoidance } & \multicolumn{2}{c}{$\begin{array}{c}\text { Acceptance of } \\
\text { waiting }\end{array}$} \\
\hline & $\mathrm{M}$ & $\mathrm{SD}$ & $\mathrm{M}$ & $\mathrm{SD}$ \\
\hline None & 3.03 & 1.70 & 3.16 & 1.65 \\
1 & 3.69 & 1.83 & 2.99 & 1.63 \\
2 & 3.54 & 1.69 & 3.46 & 1.82 \\
3 or more & 3.55 & 1.78 & 3.65 & 1.77 \\
\hline
\end{tabular}

\section{Relationship between the attitude towards death and work parameters in ambulance workers}

By title only the Avoidance subscale showed a significant difference between groups $(F(4,598)=12.110, p<0.001)$. Medical doctors and paramedics showed the lowest score in Avoidance, with ambulance technicians showing the highest. Ambulance drivers and nurses had an intermediate score (Table 5).

\begin{tabular}{lcc}
$\begin{array}{l}\text { Table 5. Avoidance subscale by the title of ambulance } \\
\text { workers }\end{array}$ & \multicolumn{2}{c}{ Avoidance } \\
\cline { 2 - 3 } Title & $\mathrm{M}$ & $\mathrm{SD}$ \\
\hline Medical doctor & 2.80 & 1.85 \\
Paramedic & 2.81 & 1.55 \\
Ambulance technician & 4.23 & 1.60 \\
Ambulance nurse & 3.62 & 1.77 \\
Ambulance driver & 3.67 & 1.79 \\
\hline
\end{tabular}

Work hours/month and Avoidance subscale showed a significant relationship $(t(628)=-2.562, p=0.012)$. Workers with 168 work hours/month had a higher Avoidance score $(\mathrm{M}=3.48, \mathrm{SD}=1.75)$ than those who work less than 168 hours per month $(\mathrm{M}=2.98, \mathrm{SD}=1.69)$.

The number of jobs showed a non-significant relationship with attitude towards death, and there was a non-significant association between years spent working and attitude towards death.

\section{Relationship between attitude towards death and health and risk parameters in ambulance workers}

Exercise and attitude towards death showed a significant relationship on the Acceptance as an escape subscale $(F(2,631)=3.367, p=0.036)$. Ambulance workers who did not do regular exercise showed a higher score on this subscale $(\mathrm{M}=2.85, \mathrm{SD}=1.43)$ than those who exercise weekly/monthly $(\mathrm{M}=2.65, \mathrm{SD}=1.11)$ or a few/two times a week/daily $(\mathrm{M}=$ $2.76, \mathrm{SD}=1.25)$. Smoking and alcohol consumption did not show a significant relationship with attitude towards death.

\section{Discussion}

Several questionnaires are used in Hungary to examine attitudes towards death, including the Revised Death Attitude Profile Scale Questionnaire (DAP-R) - which was developed by Wong et al. (1994). To the best of our knowledge, the official translation of this questionnaire has not yet been completed in Hungary. Although Varga et al. (2009) provide a translation in their study, it turned out after a follow-up research that it is not an inviting translation. The first part of our study involved translating the original questionnaire into Hungarian with the help of a professional translation group. It was then translated back into the original English by another professional group. No significant differences were found between the inverted and the original questionnaire. Report was taken of the process. The subscales of the questionnaire are defined by Wong et al. (1994) as follows: Fear of death: a person's concern about passing away. Avoidance: a person avoids thinking or talking about death. Acceptance of waiting: the perception of death as a path to a happy new life. Acceptance as an escape: death is the key to deliverance from being full of pain. Neutral acceptance: the emotionless acceptance of death as part of reality. Ozcelik et al. (2018) cites Gesser as saying that there is a negative relationship between fear of death and happiness and a positive relationship between hopelessness and fear of death. They also say that the dominance of Acceptance as an escape and Acceptance of waiting subscales increase hopelessness. In addition, Neutral acceptance shows a positive relationship with happiness.

In our study, neutral acceptance was the main characteristic of the ambulance workers. This can be explained by the fact that they are directly related to deaths for a very short time during their work. They don't usually spend a large amount of time with dying people, so a personal relationship doesn't develop; death is part of their lives but it doesn't affect them directly or "spiritually". The exceptions to this are the deaths of people who are the same age as them or children. According to Gesser, the three forms of acceptance, including Neutral acceptance, become increasingly dominant with aging, but this correlation has not been proven among ambulance workers. In a domestic survey by Békés (2000) among men who are nonhealth workers, neutral acceptance became more dominant as the age progressed, but when the factor of religiosity was removed, this relationship ceased. According to the study, those who are very religious are characterized by Neutral acceptance - and this was not characteristic of our sample. Among male ambulance workers, Avoidance and Acceptance as an escape are dominant. Acceptance of waiting and Acceptance as an escape were especially characteristic among religious people (which is the same result as Ozcelik's results for nurses working in Turkish acute care - Ozcelik et al., 2018). Examining ambulance workers, we were able to find a significant relationship with death avoidance with several factors, such as the number of children, higher education, full-time workers and physicians. However, no significant relationship was found between marital status, number of years spent at work, number of jobs, smoking and alcohol consumption, and attitudes towards death.

\section{Conclusions}

The translation of the DAP-R questionnaire conducted in the first part of our study can be a referential basis for further 
studies in Hungary. Comparing our results to other studies in the international literature, the fear of death attitude was less, and neutral acceptance (more balanced psychological attitude) was typical. The fear of death that appears in our data requires more studies for clarification.

\section{Conflict of interests}

The authors have no conflict of interests to declare.

\section{Ethical approval}

The research was permitted by the National Medical Research Ethics Committee (ETT TUKEB number: 11994-2/2018).

\section{Průzkum postojů pracovníků záchranné služby ke smrti}

\section{Souhrn}

Úvod: Postoje ke smrti jsou faktory ovlivňující vyhoření a tyto postoje mají různé projevy a kategorie (strach ze smrti, vyhýbání se konfrontace se smrtí, neutrální přijetí smrti, přijetí smrti jako začátku nové kapitoly, přijetí smrti jako úniku).

Metody: Studie byla provedena mezi 1. březnem 2018 a 28. únorem 2019 mezi zaměstnanci „Národní záchranné služby“ a členy organizace „Národní ambulantní pracovníci Mad’arské komory zdravotnických pracovníkü“. Pro tuto studii jsme použili revidovanou verzi dotazníku Death-Attitude Profile (DAP-R), kterou vytvořili Wong/Reker/Gesser. Mad'arská verze dotazníku neexistovala, a proto byl vytvořen jeho překlad. Odpovědi respondentů byly analyzovány pomocí statistického programu SPSS 25.0 . Výsledky: Překlad dotazníku byl úspěšný. Studie se zúčastnilo celkem 669 pracovníků záchranné služby - lékaři záchranné služby, záchranáři, technici v sanitkách, zdravotní sestry pracující v sanitkách, řidiči sanitky (muži $-n=584,87,3 \%$, ženy - $n=83$, 12,4 \%; průměrný věk: $42,40(S D=10,41$, rozsah = 20-64)). Při analýze dat se ukázalo, že kategorie „strach ze smrti” měla nejmenší zastoupení $(M=2,77, S D=1,30)$ a kategorie „neutrální přijetí smrti” ( $M=5,86, S D=1,22)$ zastoupení největší.

Závěr: Překlad dotazníku DAP-R provedeného v první části naší studie lze použít jako referenční základ pro další studie v Mad'arsku. Při srovnání našich výsledků s jinými studiemi v mezinárodní literatuře je kategorie „strach ze smrti” zastoupena ve větší míře, než se očekávalo; nejčastějším postojem pracovníků záchranné služby ke smrti je „neutrální přijetí smrti”.

Klíčová slova: Mad'arsko; postoj ke smrti; záchranáři

\section{References}

1. Békés V (2000). Are you afraid of death? Correlates of fear of death. Kharón Thanatológiai Szemle 4(4): 5-65.

2. Buckman $\mathrm{R}$ (1993). Communication in palliative care: A practical guide. In: Doyle D, Hanks GWC, MacDonald N (Eds). Oxford Textbook of Palliative Medicine (pp. 51-69). Oxford: Oxford Medical Publications.

3. Copp G (1998). A review of current theories of death and dying. J Adv Nurs 28(2): 382-390. DOI: 10.1046/j.13652648.1998.00794.x.

4. Corr CA (1992). A Task-Based Approach to Coping with Dying. Omega (Westport) 24(2): 81-94. DOI: 10.2190/CNNF-CX1PBFXU-GGN4.

5. Corr CA (2015). The death system according to Robert Kastenbaum. Omega (Westport) 70 (1): 13-25. DOI: 10.2190/ OM.70.1.c.

6. Corr CA, Corr DM, Border TC (2013). Death and dying, life \& living. Boston, MA: Wadsworth Cengage Learning.

7. Donnelly E, Siebert D (2009). Occupational risk factors in the emergency medical services. Prehosp Disaster Med 24(5): 422-429. DOI: $10.1017 /$ s1049023x00007251.

8. Edlich RF, Kübler-Ross E (1992). On death and dying in the emergency department. J Emerg Med 10(2): 9-225. DOI: 10.1016/0736-4679(92)90231-h.

9. Glaser BG, Strauss AL (1965). Awareness of dying. [online] [cit. 2018-02-24]. Available from: https://books.google.ae/ books?id=opcuDwAAQBAJ

10. Hegedüs K, Pilling J, Kolosai N, Bognár T (2001). Attitudes of nurses and physicians towards death and dying. Lege Artis Med 11(6-7): 492-499.

11. Kastenbaum R, Thuell S (1995). Cookies Baking, Coffee Brewing: Toward a Contextual Theory of Dying. Omega (Westport) 31(3): 175-187. DOI: 10.2190/LQPX-71DE-V5AAEPFT.

12. Kübler-Ross E, Byock I (1969). On death and dying: what the dying have to teach doctors, nurses, clergy $\&$ their own families. New York: Scribner.
13. Kulcsár Z (2002). Health psychology. ELTE Eötvös Publishing House, pp. 117-147.

14. Olsen JC, Buenefe ML, Falco WD (1998). Death in the emergency department. Ann Emerg Med 31(6): 758-765. DOI: 10.1016/s0196-0644(98)70236-7.

15. Ordog GJ (1986). Dealing with the sudden death of the emergency patient. Can Fam Physician 32: 797-802.

16. Ozcelik H, Aksoy F, Sonmez E, Fadıloğlu Ç (2018). Attitudes to death of nurses in Turkey and factors affecting them. Hos Pal Med Int Jnl 2(6): 303-309. DOI: 10.15406/ hpmij.2018.02.00112

17. Parrish GA, Holdren KS, Skiendzielewski JJ, Lumpkin OA (1987). Emergency department experience with sudden death: a survey of survivors. Ann Emerg Med 16(7): 792-796. DOI: 10.1016/s0196-0644(87)80577-2.

18. Pattison EM (1977). The experience of dying. PrenticeHall. [online] [cit. 2018-02-24]. Available from: https:// books.google.ae/books/about/The_experience_of_dying. html?id=JT5rAAAAMAAJ\&redir_esc =y

19. Pék E, Székely-Benke Z, Betlehem J, Fullér N (2015). Comparative examination of the attitudes of ambulance workers and ambulance officers towards death and dying. Orv Hetil 156(40): 1618-1624. DOI: doi.org/10.1556/650.2015.30266.

20. Schmidt TA, Norton RL, Tolle SW (1992). Sudden death in the ED: Educating residents to compassionately inform families. J Emerg Med 10(5): 643-647. DOI: 10.1016/07364679(92)90155-m

21. Varga ZK, Baksa D, K-Szilágyi A (2009). Investigation of death attitudes and correlations in critically ill nursing populations: among nurses working in intensive care units and hospice care. Kharón Thanatológiai Szemle 9(2): 8-54.

22. Wong PTP, Reker GT, Gesser G (1994). The Death Attitude Profile-Revised (DAP-R): A Multidimensional Measure of Attitudes Towards Death, pp. 1-26. [online] [cit. 2020-02-02]. Available from: http://www.drpaulwong.com/wp-content/ uploads/2018/03/Death-Attitude-Profile-Revised-DAP-R-WongReker-Gesser-1994-Paper-NEW.pdf 


\section{Annex}

\section{The questionnaire translated into Hungarian:}

Kérjük, olvassa el figyelmesen, majd jelölje egy 1-től 7-ig terjedő skálán mennyire ért egyet az egyes állításokkal. Ha nagyon egyetért, jelölje be a 7-es számot, ha nagyon nem ért egyet, akkor az 1-est, ha pedig bizonytalan, akkor a 4-est. Azonban amennyire teheti, kerülje a határozatlan kategóriát! Fontos, hogy minden kérdésre válaszoljon. Előfordulhat, hogy egyes állítások nagyon hasonlónak tűnnek, ám fontos, hogy mindegyikre külön válaszoljon annak érdekében, hogy az attitűdök között található finom különbségeket feltárhassuk.

\begin{tabular}{|c|c|c|c|c|c|c|c|}
\hline A halál kétségkívül kegyetlen dolog & 1 & 2 & 3 & 4 & 5 & 6 & 7 \\
\hline Saját halálom lehetősége szorongást kelt bennem & 1 & 2 & 3 & 4 & 5 & 6 & 7 \\
\hline Mindenképp elkerülöm azt, hogy a halálra gondoljak & 1 & 2 & 3 & 4 & 5 & 6 & 7 \\
\hline Hiszem, hogy halálom után a mennyországba kerülök & 1 & 2 & 3 & 4 & 5 & 6 & 7 \\
\hline A halál véget vet minden gondomnak & 1 & 2 & 3 & 4 & 5 & 6 & 7 \\
\hline A halált természetes, elkerülhetetlen, tagadhatatlan ténynek kell tekintenünk & 1 & 2 & 3 & 4 & 5 & 6 & 7 \\
\hline Zavarba ejt a halál megmásíthatatlansága & 1 & 2 & 3 & 4 & 5 & 6 & 7 \\
\hline A halál belépés a végső megnyugvás helyére & 1 & 2 & 3 & 4 & 5 & 6 & 7 \\
\hline A halál megmenekít ettől a szörnyủ világtól & 1 & 2 & 3 & 4 & 5 & 6 & 7 \\
\hline Valahányszor felmerül bennem a halál gondolata, elhessegetem magamtól & 1 & 2 & 3 & 4 & 5 & 6 & 7 \\
\hline A halál megszabadít a fájdalomtól és a szenvedéstől & 1 & 2 & 3 & 4 & 5 & 6 & 7 \\
\hline Mindig megpróbálok nem gondolni a halálra & 1 & 2 & 3 & 4 & 5 & 6 & 7 \\
\hline Hiszem, hogy a mennyország sokkal jobb hely lesz, mint ez a világ & 1 & 2 & 3 & 4 & 5 & 6 & 7 \\
\hline A halál az élet természetes velejárója & 1 & 2 & 3 & 4 & 5 & 6 & 7 \\
\hline A halál Istennel való egyesülés az örök üdvösségben & 1 & 2 & 3 & 4 & 5 & 6 & 7 \\
\hline A halál egy új és nagyszerủ élet ígéretét jelenti & 1 & 2 & 3 & 4 & 5 & 6 & 7 \\
\hline Sem nem félek a haláltól, sem nem várom & 1 & 2 & 3 & 4 & 5 & 6 & 7 \\
\hline Erős halálfélelmem van & 1 & 2 & 3 & 4 & 5 & 6 & 7 \\
\hline Teljesen elkerülöm a halál gondolatát & 1 & 2 & 3 & 4 & 5 & 6 & 7 \\
\hline A halál utáni élet gondolata aggodalommal tölt el & 1 & 2 & 3 & 4 & 5 & 6 & 7 \\
\hline Rémülettel tölt el a tény, hogy a halál mindennek a végét jelenti, amit csak ismerek & 1 & 2 & 3 & 4 & 5 & 6 & 7 \\
\hline Várom, hogy a halálom után újra találkozzam szeretteimmel & 1 & 2 & 3 & 4 & 5 & 6 & 7 \\
\hline Úgy tekintek a halálra, mint ami megszabadít a földi szenvedéstôl & 1 & 2 & 3 & 4 & 5 & 6 & 7 \\
\hline A halál egyszerủen az életfolyamat része & 1 & 2 & 3 & 4 & 5 & 6 & 7 \\
\hline Úgy tekintek a halálra, mint egy örökkévaló és áldott helyre vezető útra & 1 & 2 & 3 & 4 & 5 & 6 & 7 \\
\hline Megpróbálok egyáltalán nem foglalkozni a halál problémájával & 1 & 2 & 3 & 4 & 5 & 6 & 7 \\
\hline A halál a lélek csodálatos felszabadulását jelenti & 1 & 2 & 3 & 4 & 5 & 6 & 7 \\
\hline Ha a halálra gondolok, a túlvilágba vetett hit jelent számomra megnyugvást & 1 & 2 & 3 & 4 & 5 & 6 & 7 \\
\hline Úgy tekintek a halálra, mint ami megszabadít az élet terhétől & 1 & 2 & 3 & 4 & 5 & 6 & 7 \\
\hline A halál se nem jó, se nem rossz & 1 & 2 & 3 & 4 & 5 & 6 & 7 \\
\hline Várom a halál utáni életet & 1 & 2 & 3 & 4 & 5 & 6 & 7 \\
\hline Aggaszt, hogy nem tudhatom mi fog történni a halálom után & 1 & 2 & 3 & 4 & 5 & 6 & 7 \\
\hline
\end{tabular}

Death Attitude Profile-Revised (DAP-R): Scoring Key

Fear of Death (7 items) 1, 2, 7, 18, 20, 21, and 32

Death Avoidance (5 items) 3, 10, 12, 19, and 26

Neutral Acceptance (5 items) 6, 14, 17, 24, and 30

Approach Acceptance (10 items) 4, 8, 13, 15, 16, 22, 25, 27, 28, and 31

Escape Acceptance (5 items) 5, 9, 11, 23, and 29 